\title{
Certificate of Land Rights in the Legal Philosophy of Notary
}

\author{
Prof. Dr. Ade Saptomo ${ }^{1}$, and Dr. B. F. Sihombing ${ }^{2}$ \\ ${ }^{1}$ Professor Law Science, Faculty of Law, Universitas Pancasila \\ ${ }^{2}$ Lecturer Law Science, Faculty of Law, Universitas Pancasila (UP)
}

\begin{abstract}
This study aims to analyze the legal issues faced with regard to society and land, birth certificates and legal reviews of the role and duties of a notary in Indonesia. The method in this research is to use normative legal research, collect and analyze secondary data, namely books, diaries, laws and regulations, court decisions, legal theories and opinions of leading legal scholars who to analyze statutory regulations and various literatures related to land title certificates. The results of the study found that the importance of land title certificates, as a person's control over land, is a human right that deserves protection and assurance of certainty of ownership and is contained in a rule as regulated in UUPA No. 5 of 1960. Then, the role of a notary as an official which is given the authority by the state, especially the making of authentic deeds, as regulated in UUJN No. 30 of 2004, the Notary Public needs to use a legal philosophy approach to ensure legal protection for the community using his services through accurate case mapping, legal corrections, linguistic improvements and comprehensive services.
\end{abstract}

Keywords: Certificate, UUPA No.5/1960, UUJN No.30/2004, Notary, legal philosophy, Indonesia

\section{Introductions}

According to Mello (2019: 3). the nature of the law or land law has always been with humans since the first hunters and gatherers began to form tribes into community cities that were arranged to live in communities. Meanwhile, Finnis (2011) in Mello (2019: 4-5) states that natural law and natural rights are rules recognized by groups of people who form societies that follow these laws to maintain peace among all who live by these natural laws as follows: (a) Natural legal rights are given to humans by God who guides tribes, states, or cities to live according to natural laws which treat all people as equals in pursuit of life, freedom, and the right to own property; (b) This convenient form of code creates a system of laws that asserts the highest direction for behavior in the community, provides constitutional validity for all arrangements that affect society subject to power and legitimate grounds for obeying natural law established by its officials; (c). Legal authority depends on justice; (d). Coercive truth must be part of the law to carry out punishment among persons who obey this law; and (d) The practical reasonableness of the law forms the authority to defend the country from invaders, both domestic and international, with the strength of conscience from crimes against the state or its citizens.

According to Iman Soetiknyo (1987) in Wiradi (2002: 3) that from a legal perspective, the philosophy underlying the 1960 Law on Basic Agrarian Basic Regulations (UUPA-1960) is what is called a "monodualist" foundation, while From a socio-political perspective, UUPA-1960 which refers to article-33 of the UUD-45 (the original), is essentially "neo-populist" (not socialist, not capitalist), even though Bung Karno named it with the term "socialism a'la Indonesia. ". However, this neo-populist characteristic is somewhat reduced by its derivative law, namely Law no.56 / 1960 known as the Landreform Law, concerning the stipulation of an area of agricultural land with a minimum limit of 2 hectares is totally contrary to the neopopulist spirit ( Wiradi (2002: 3)).

The birth of a piece of paper that has the quality of the legality of the statement printed on it is important, but more importantly why there is a certificate and what is behind the certificate. To get this answer, this paper begins with the birth of society itself. Before there was a community, of course what existed before was an unlimited stretch of land. On that land, it is still empty, there are no humans, let alone people. Even though, the existence of a human being on the land exists, but there is no meaning whatsoever, it is different 
when there are other humans besides the first named human then at that time between humans identify each other and the results of identification are the differences of each. . With each of these differences make the potential for contact. Furthermore, mutual contact is followed by the presence of other humans in the same land or place environment. The greater the number of human presence, the social contact occurs. The more people in social contact will encourage them to take action, one action followed by another so that interaction occurs.

This interaction involves many humans so that social interaction occurs. In the course of social interaction, habits are born, these habits become guidelines for the community itself and eventually become guidelines followed by many people. The crowd increasingly believes that behavior, actions that do not or deviate from the habit are agreed to need to be sanctioned. That's when social norms were born. Therefore, the existence of law is very necessary because law is a social norm that aims to regulate social life as an order or guidance in behavior to protect social life and to maintain social life (Widowati, 2013: 1). According to Indonesia Land Degradation Neutrality National Report (2015: 5). understanding of land is a major factor and an important input to meet human needs as the backbone of agriculture, industry, mining, public housing, and other human activities. Broadly speaking, changes in land use are the result of complex interactions and are influenced by several factors such as: population growth, intensive and extensive agricultural practices, urbanization, and economic development causing land use change to cause problems for the environment (see Kelarestaghi and Jeluodar, 2009 and Giri et al. 2003 in Indonesia - Land Degradation Neutrality National Report, 2015: 5)

Problems related to land in Indonesia often lead to prolonged conflicts between people and people and people and legal entities. This is caused by land which is an important factor in the life of a community. Demand for land when it increases sharply, resulting in more individualistic and concentrated commercialization of land by some owners, which causes the function of land to shift and turn into an economic and industrial function, land control and ownership tend to be distributed among groups and groups and access to land becomes increasingly difficult (Aryono, 2017). Disputes over land seem endless and always occur in the world as well as in Indonesia due to the human need for land which continues to increase along with the rate of population growth (Permadi, 2016: 448).

In Indonesia, there are several main issues concerning land that can lead to disputes, namely: (a) Land that has multiple certificates; (b) Conflict over control and ownership of State lands; (c) Conflicts regarding ownership due to inheritance; (d) Conflict regarding land that has not been certified, namely the status of the right is still customary land and is still land with western rights attached; (e) The process of registering the rights of the prona; (f) Control and occupation of land from ex-usufructuary rights that have expired and are not extended; (g). and many others (Permadi, 2016: 448-449). Land and resource conflicts are increasingly a source of violence in Indonesia, for example the dispute in Mesuji, Lampung Province is about industrial tree plantations, but they can also easily become mines or oil palm plantations, and this was the cause of initial disputes related to land grabbing that had already occurred. decades so that the conflict has become much more complex as political and economic stakes increase (Jones, www.cogitasia.com/,15/8/2013), and the Ministry of Agrarian and Spatial Planning / State Land Agency (ATR / BPN) notes that October 2020, conflict disputes and court cases regarding land numbered 9,000 cases (Fadli, Kompas.com - 04/11/2020).

Based on the various descriptions and land problems above, this is what interests researchers to analyze land rights certificates in notary law philosophy, which consists of: (a). Community and Land, (b). Birth of Land Certificate, and (c) Legal Review on the Role and Duties of a Notary in Indonesia because the certificate is a strong evidence as referred to in Article 19 UUPA 1960. The certificate is issued for the purpose of proving the right holder concerned in accordance with physical data and data. juridical that has been registered in the land book listed in the certificate must match the data contained in the land book and the relevant measuring document. Thus, the issuance of a land title certificate guarantees legal certainty and legal protection to prevent future disputes, legal claims caused by parties who feel aggrieved by the issuance of a land certificate. 


\section{Methodology}

Legal research is also a process to determine legal rules, legal principles, and legal doctrines in order to address legal issues at hand. The method in this research is to use normative legal research, normative legal research is research conducted to collect and analyze secondary data. In normative legal research, usually only secondary data sources are used, namely books, diaries, laws and regulations, court decisions, legal theories and the opinions of leading legal scholars (Marzuki, 2005: 13) which aims to analyze (Budiono, 2016) existing laws and regulations and various literatures related to the issue of land title certificates.

\section{Statement of Problem}

Problems related to land affairs often lead to prolonged conflicts between people and people and people and legal entities. This is due to the factor of increasing population and legal factors, legal facts show that there is injustice. Land certificates as a guarantee of legal certainty and legal protection in order to prevent future disputes, lawsuits caused by parties who feel aggrieved by the issuance of a land certificate become a critical issue because ownership of land certificates is not just to fulfill administrative requirements and only formal evidence but it is very important. Therefore, it is important to understand the land title certificate in the philosophy of notarial law related to why there must be a certificate and what is behind the certificate has attracted researchers to conduct a more in-depth study related to legal issues faced with regard to Society and Land, Birth. certificate as well as a legal review of the role and duties of a notary in Indonesia.

\section{Discussions and Results}

\subsection{Community and Land}

Only one year after the proclamation of 1945, namely 1946, Bung Hatta gave a speech regarding the land issue: "Why Land? Yes, because among various agrarian sources, on the ground lies the heart of social, economic and political problems "(Wiradi, 2002: 2). Land as a source of human life, where people can look for a source of income. Land position is very much influenced by the socio-economic features of a society. There are several types of socio-economic features in the history of social development, where the position of land is also determined by each of these types, namely: First, the features of pre-capitalist society: Land is seen as a means of production controlled communally. There is no concept of ownership in this type of society. Land has a social function. Individuals can manage and utilize land without having to own it. Customary land is one form of control over the means of production in this type of society. The authority to regulate the use and management of land is determined by applicable customary law.

Second, the character of a capitalistic society: Land is seen as a means of production that is owned individually. In this concept, individuals have rights and can freely own land or transfer it through market mechanisms to other people. Third, socialistic society: Almost the same as pre-capitalist, in this society, land is seen as a means of production which is controlled collectively. The concept of ownership is also not justified. The difference with the pre-capitalist system is that this collective control is under the authority and control of the State. As we know, Indonesia is an archipelagic country so that lands still apply customary law where the land is located, as we know the old agrarian law, namely agrarian law before Law No. 5 of 1960 was enacted, some are "written" laws, and some are "unwritten" laws.

As part of written agrarian law, the rules are derived from western agrarian law, which is a legacy of the Dutch colonial government. Written agrarian law, among others, as contained in Agrarische Wet, stbl. 1870 no. 55, Agrarisch Besluit, stbl. 1870 no. 118 and its implementing laws, or those contained in a statutory book that has been systematically compiled, codified, namely in the Civil Code (Burgerlijk Wetboek (BW)). Whereas agrarian law is unwritten, its principles are based on the customary law of the Indonesian nation. Namely the existing law, obeyed and implemented by all Indonesian people, before the Dutch colonized the Republic of Indonesia.

The old agrarian law, which was in effect in Indonesia before the enactment of UUPA No.5 of 1960, has a dualistic character. This means that the agrarian law is based on western law (written), apart from the traditional (unwritten) law of the Indonesian people. The customary law that is enforced in one area is different from other regions depending on the environment of each customary law. To guarantee legal certainty, the defense law unification was carried out by establishing UUPA No. 5 of 1960 concerning Basic 
Agrarian Principles. Because the prevailing agrarian law was partly composed based on the objectives and principles of the colonial government (the Netherlands), so that it was against the interests of the state.

Before the issuance of UUPA no. 5 of 1960, which opens the right to land, namely in article 51 paragraph 7 IS, in Staasblad 1872 No. 117 regarding Agraris Eigendom Recht, gave Indonesians eigendem rights (property rights). This is also equated with eigendom rights contained in book II BW, but these rights are given not to Indonesians. According to Gautama (1981) in Sihombing (2016: 132), in addition to the regulations of article 51 paragraph 7 IS, at Staasblad 1872 No. 117 there is again Staasblad 1870 No.179 concerning the prohibition of alienation of land (grand vervreemdingsverbod), namely the right of ownership (adat) to land cannot be transferred by native Indonesians to non-Indonesian (native) and therefore all agreements aimed at transferring said right, either directly or indirectly, is null and void because of the law.

With the dualism of rules governing land rights to make them uniform and UUPA no. 5 of 1960 is nationalist in nature, which is enforced nationally in which all Indonesian citizens use the law. The basis for the nationality of agrarian law which has been formulated in UUPA No. 5 of 1960 as follows:

a. The territory of Indonesia which consists of earth, water, space, and natural resources contained therein constitutes a single homeland of the Indonesian people who are united as the Indonesian nation (article 1 UUPA No.5 of 1960).

b. The earth, water, space, and the natural resources contained therein are gifts from God Almighty to the Indonesian people and constitute national assets. For this reason, this wealth must be maintained and used for the greatest prosperity of the people (articles 1,2,14 and 15 of UUPA No. 5 of 1960).

c. The relationship between the Indonesian nation and the earth, water, space, and the natural resources contained therein is eternal, so no one can break it (article 1 UUPA No.5 of 1960).

d. The state as the power organization of the nation and the Indonesian people is given the authority to control the earth, water, space and natural resources contained therein for the greatest prosperity of the people (article 2 UUPA No. 5 of 1960).

e. The existence of customary rights as the right of customary law communities is recognized. This recognition is accompanied by the condition that the customary rights still exist, do not conflict with national interests and higher levels of legislation (article 3 UUPA No. 5 of 1960).

f. The subject of rights that has a full relationship with the earth, water, space and natural resources contained therein are Indonesian citizens without distinction between genuine and non-original. In principle, a legal entity does not have a full relationship with the nature contained therein (articles 9, 21, and 49 UUPA No.5 of 1960)

g. Laying the foundations for unity and simplicity in the land law.

With the enactment of provisions of UUPA no. 5 of 1960, then the authority in the form of control of lands by legal associations was restricted from the authority in the previous period because since then all authority regarding land issues was centered on state power. Then, in order to overcome there are 2 (two) legal systems in one area after the enactment of UUPA No. 5 of 1960, it is necessary to change the customary land law before and after the enactment of the UUPA, one of which is the conversion of land rights, which is the adjustment of land rights subject to the old legal system, namely land rights according to Western Civil Law and lands subject to customary law to enter the legal system under UUPA No. 5 in 1960.

For example, in this case the sale and purchase of land, before the enactment of UUPA No. 5 of 1960, regarding the sale and purchase of land, it is often done verbally only, namely the seller. That is why it was said that it was formless. Then, developed by making a sale and purchase letter between the two parties. Buying and selling land is a legal act of handing over land rights by the seller to the buyer. Other changes that occur for example in terms of expiration. In customary law, this dalu concerns land ownership rights. Previously, a parcel of land that had been cleared with the permission of the customary holder or the authorized customary head, then after several years it was not cultivated / replanted it could be given another 
/ new designation to the party that formed it, due to the influence of the length of time and the land had returned to ulayat village rights.

\subsection{Birth of Land Certificate}

If we pay close attention, there is currently a power that globalizes an idea and its results in material life for human beings living on this earth, namely material ideas. the idea must be present and everywhere and moved everywhere. Initially it was not easy because it met with local forces so that it seemed as if the efforts to globalize had no obstacles. Gradually the implementation seemed more and more persistent, especially when the adventurers of Western Europe tried to find and find countries outside Europe to control and take their wealth from. Historically, the adventures of globalization itself have actually occurred since the XV century Christopher Columbus' first voyage which took him, in October 1492, to the coast of an island in the Caribbean Sea and found the American continent to be the beginning of globalization again (Toussaint, 2019). The discovery of the American continent by the Europeans led by Columbus brought a large movement of Europeans to the Americas, and finally followed the movement of movement from the east.

The American continent becomes something very interesting considering that at that time the results of the adventure in America itself could really fulfill the expectations that were craved by many people, especially from among themselves. The adventurers from Europe who came to the Americas at that time were not just any adventures considering that if their adventurous journey was not accompanied by total courage, the adventure itself would not be successful. This can be imagined when they are outside their own continent who dare to bear high risks, even their death is at stake. This condition gives birth to the mental mentality of the individual struggling individually and competing with each other so that it fosters the emergence of a struggling mental situation and condition, competing individually. This is what some people say the beginning of the birth of individualism, which is then symbolized in certificates, such as certificates of land title.

In communal societies, customary law colors all arenas of social, cultural, economic and local political life in the local community. The position of customary law is very strong and deeply rooted in the culture of the local community, so that it can be further imagined about the customary atmosphere which seems to be untouched by any outside power and force. Land stretches and large areas of land are assets that have no subject, so that anyone who is on the land and land is considered as a subject who is allowed to make absolute use of it. The above assumption arises following a religious view that the land is part of the divine creation universe that is available to provide divine mercy to His creatures.

Humans as one of His creatures strive to seek and continue to seek new sources of life than their previous lives. Land, of course, was seen as a source of life, but considering the land and land at that time were so vast, even immeasurable in his mind that land could only be controlled ipso facto. This means that land is considered to be controlled in real terms if the land in question is occupied, utilized, cultivated and cared for by the settlers and the cultivators. The more land and land that is occupied, cultivated and utilized in such a way in reality, the more intense and strong and unspeakable the right of ownership will be. On the other hand, the more land and land are neglected and neglected, the tenure rights in question will fade and disappear. If this is the case, the individual rights will soon be transformed back into free land.

At that time, the concepts that were born, lived and grew in the customary atmosphere as outlined above are still valid. The native kings of that time were not cultivators of the land, and therefore neither ipso facto were the rulers of lands and lands. The native kings at that time were not cultivators of the land, and therefore neither ipso facto became the masters of the land and land in question. Indigenous rulers are only the rulers of an area or area of certain jurisdiction along with the residents who reside and live in that area. Thus, during the time of the indigenous kings at that time, there was no change in the concept of control over land. This situation can be felt by its existence, especially in Java, outside Java, of course the atmosphere of customary law is still very intact.

During the colonial era, the arrival of the colonial government in Bumi Nusantara made the customary law atmosphere change slightly. Changes were inevitable given the social relationship between the local community and the colonial government. Changes caused by the practices of social, political, and economic 
relations occurred considering that the colonial government brought its concepts of the country to some extent, which would certainly negate the concepts of customary law, which in the case of land, for example, have stated that rights and control over land are realized " for the sake of fact "as stated above. It is different from the Western concept because the initial concept argued that rights, also land rights, must be published and their issuance must also come from rights. That is, the right to own land or land issued is not an ipso facto reason, but an ipso jure reason.

In this connection, the Dutch East Indies government, which had a European concept from the beginning, argued that the governor's rights to land were a right obtained through the ipso jure principle from the native rulers, either through contracting lange or korte verklaringen. Starting from this premise, control practices are not based on ipso facto but ipso jure is sought for a juridical justification, namely the issuance of Agrarische Wet in 1870 (Ind. Stb. 19870 No. 55) which contains a decree that land in Java and Madura, on which it cannot be proven the existence of eigendom rights is the state domin. In the next five years, with an ordinance known as the Algemene Domeinverklaring, which was published in Ind. Stb. 1875 No. 1991, Agrarische Wet also stated that it applies to areas outside Java and Madura. This juridical factor is then suspected as a determining factor that influences or eliminates the absolute customary rights of indigenous peoples and their citizens over lands inherited from their ancestors.

The combined aspect of the two concepts above, can also be read when people's rights are still recognized, although not de jure recognition as absolute property rights, but de facto recognition as bezitrech which even so can be applied for de jury recognition as eigendom. This is an ipso jure right that comes from the government as the ruler of the State for the recognition of an ipso facto. However, it should be borne in mind that Europe does not recognize the concept of rights and origins of rights, although, indeed, applications for such eigendom rights on the ground are rare. Residents of the local community still think that the facts show their existence on land, especially if their existence on the land they have occupied has been going on for a long time, from generation to generation, is strong enough to prove their rights to the land that has been occupied and utilized.

The colonial policy regarding the recognition of the rights of the people, which was conceptualized as bezitrecht, was real, if it was getting longer and harder for us to continue, especially in the post-colonial era during the New Order government. When national development demands the use of land lands nationally for more productive purposes, on the one hand, and on the other hand, lands and lands are increasingly scarce so that with such high population density, land grabbing is inevitable. In the process of struggle, justifications for rights based on law are expanded and new logical arguments are built. According to Wignyo soebroto (2020), state law which is also called national law - now no longer prioritizes moral content and moral truth or the value of rechtswaardigheid to guarantee its legitimacy, but rather prioritizes the power of certainty to apply or rechtzekerheid value. This is the process of secularization which is also called the process of legal positivisation. "Law" can only be viewed and recognized as law when the law is clearly an explicit command.

The law is sovereign, as Austin said that "(positive) law is the command of the sovereign". Law is no longer abstract principles that cannot be shown where and how the clear and firm formulations are, and what are their characteristics which suggest that "law" is really law. The law and the concept of positivists are no longer just ius, but must truly be characterized as lex which law should be the basis (soetandyo.wordpress.com/2010/08/19). Choice of Law. The number of community members may be countless who do not understand and understand, especially for those who have never felt an interest in freeing themselves from the realm of customary law thinking. In their cognitive map, they insist on unanimously referring to the old normative structure. National law (state law), which is built based on formal and material sources, is still perceived as foreign law, which is not easily recognized, understood and understood, let alone lived by the local community.

In the issue of land rights, for example, millions of people who mainly live in remote and inland areas do not understand how it is possible that the fact of land tenure that has been going on for generations can suddenly be defeated by the titles contained in the certificates that are created in an abstracto. According to 
Sumardjono (2001) in Herrayani et, al. (2019: 284), the fundamental thing in land problems in Indonesia is the weakness of legal recognition and protection related to the existence of indigenous peoples. According to Herrayani et, al., 2019: 284). Conflicts in land use between various development sectors are caused by two factors as follows:

a. The factor of increasing population, with increasing population, the scarcity of land and deterioration of quality which causes poverty, narrow job opportunities and unequal access to the acquisition of land use and the increasingly pressing rights of indigenous peoples;

b. Legal factors, legal facts show that there is injustice, there are landowners who control a very large area of land but are unable to cultivate it. On the other hand, there are farmers but only as cultivators, farmers do not own land at all and only become agricultural laborers. On the other hand, landlords get abundant benefits from the land they control and are cultivated and managed by small farmers (agricultural laborers). Inequality of land ownership and injustice over access to land by farmers have created thoughts that demand a sense of justice, thus giving birth to movements to change a new legal order that is more just and more pro-poor, the peasants and workers. Therefore, agrarian reform was born, which in principle is land for the peasants and justice for all, one legal system that is just for all the people.

Thus, the importance of land title certificates which can be interpreted as control of a person or individual over land is a human right that deserves protection and assurance of ownership. Legal certainty guarantees given to these individuals must be embodied and contained in a statutory regulation as regulated in Article 19 UUPA No. 5 of 1960 and the obligation for holders of land ownership rights to register their land is regulated in Article 23 UUPA No. 5 of 1960. According to Wahanisa et.al. (2010), ownership of a land certificate is not only the fulfillment of administrative requirements, and formal evidence but more than that, as a guarantee of legal certainty because the certificate is a proof of rights which is valid as a means of proof that strong regarding the physical data and juridical data contained therein, as long as the physical data and juridical data are in accordance with the data contained in the relevant measuring letter and land book.

Thus, legal certainty of land and land ownership is very important to note, and in Indonesia, there are types of land titles and land ownership which are known as follows:

Table 1: Types of Land Certificates and Land Ownership in Indonesia

\begin{tabular}{|c|c|c|}
\hline No & $\begin{array}{l}\text { Types of Land } \\
\text { Certificates and } \\
\text { Land Ownership } \\
\text { in Indonesia }\end{array}$ & Analysis \\
\hline 1. & $\begin{array}{l}\text { Freehold } \\
\text { Certificate (SHM) }\end{array}$ & $\begin{array}{l}\text { a. Article } 20 \text { UUPA No. } 5 \text { of } 1960, \text { Freehold Certificate } \\
\text { (SHM) is a type of certificate that shows that the holder } \\
\text { has full rights to a land in a certain area that has been } \\
\text { stated in the certificate. } \\
\text { b. SHM status is the strongest status for land ownership } \\
\text { because the land is already owned by someone without } \\
\text { interference or the possibility of ownership of other } \\
\text { parties. } \\
\text { c. The right of ownership to land can continue as long as } \\
\text { the owner is still alive. When the owner dies, the right of } \\
\text { ownership can be continued by the heirs as long as it } \\
\text { meets the requirements as the subject of property rights, } \\
\text { and does not conflict with the provisions of the } \\
\text { applicable laws. it can be sold to get fresh funds, it can } \\
\text { also be temporarily pawned, used as collateral to borrow } \\
\text { funds from the bank, leased, donated, and can be passed } \\
\text { on to posterity. } \\
\text { d. SHM is only applied to Indonesian citizens. }\end{array}$ \\
\hline 2. & Building & a. HGB (Hak Guna Bangunan) is an authority granted by \\
\hline
\end{tabular}




\begin{tabular}{|c|c|c|}
\hline & $\begin{array}{l}\text { Rights Certificate } \\
\text { (SHGB) }\end{array}$ & $\begin{array}{l}\text { the government or a right that is obtained to use a land } \\
\text { that is not its own for a period of } 30 \text { years which at the } \\
\text { request of the right holder binds the needs and condition } \\
\text { of the buildings and can be extended to a maximum } \\
\text { period of time. } 20 \text { years. } \\
\text { b. The certificate holder is only given the power to } \\
\text { empower the land to build buildings or other purposes } \\
\text { within a certain period of time. Property owners with } \\
\text { HGB status only own the building, while the land is still } \\
\text { state owned, and usually, developers or developers use } \\
\text { land with HGB status to renovate housing units and } \\
\text { apartments. } \\
\text { c. The HGB certificate is not necessarily free in the use of } \\
\text { the land because it must comply with the permit. } \\
\text { Another purpose that fits the criteria for an HGB } \\
\text { certificate is to own property for temporary commercial } \\
\text { use. } \\
\text { d. The benefit from property with this type of certificate for } \\
\text { foreign citizens is one way of ownership of property. } \\
\text { e. Hak Guna Bangunan can be converted into Hak Milik, } \\
\text { and the process is the same as for extension, it must } \\
\text { begin with taking care of the land office where the land } \\
\text { to be processed is located. }\end{array}$ \\
\hline 3 & $\begin{array}{l}\text { Land Ownership } \\
\text { in the Form of } \\
\text { Girik }\end{array}$ & $\begin{array}{l}\text { a. Tanah girik is land that has ownership marks based on } \\
\text { customary law. This ownership certificate is not a land } \\
\text { certificate, so its ownership is not recorded at the land } \\
\text { office, making it vulnerable to dispute. So far, the } \\
\text { existing girik evidence only serves as evidence of the } \\
\text { authority of the related land parcel, and that the tax on } \\
\text { the land has been paid by the girik owner, and the girik } \\
\text { proof is not proof of land rights. Girik is only a } \\
\text { certificate of object to land. A girik letter cannot be the } \\
\text { same as a land certificate, the position of a girik letter is } \\
\text { lower than a land certificate } \\
\text { b. Girik land is usually inherited land, customary rights } \\
\text { land. In addition, land with old rights such as land girik } \\
\text { can also come from western-owned land. For example } \\
\text { eigendom, erfpacht or opstaal. } \\
\text { c. Since UUPA No. 5/1960 was enacted, the community } \\
\text { has actually been ordered to convert land with old rights } \\
\text { to land with rights recognized by the latest government } \\
\text { law; namely land with a title of Ownership, Building Use } \\
\text { Rights or Use Rights. } \\
\text { d. Girik letter holders can also upgrade their status to } \\
\text { certificate of ownership rights (SHM) by administering } \\
\text { them to the local land office. }\end{array}$ \\
\hline
\end{tabular}

Source: Secondary data, 2020 (processed)

Based on table 1 above, it can be analyzed that Freehold Certificate (SHM) is a type of certificate that has the strongest legality when compared to Building Use Rights Certificates (SHGB) and Land Ownership in the form of Girik. SHM has no time limit and can only be owned by Indonesian citizens (WNI) and property rights can be transferred and transferred to other parties. On the other hand, ownership of SHM can be lost, if the land falls to the State for one reason or another, or the land is destroyed due to natural disasters such as landslides and collapse.

\subsection{Legal Review on the Role and Duties of Notaries in Indonesia}

The Republic of Indonesia as a constitutional state based on Pancasila and the 1945 Constitution of the Republic of Indonesia guarantees legal certainty, order and protection for every citizen. According to 
Handoyo (2003) in Erwinsyahbana (2018: 1), the essence of the rule of law is based on the concept of the theory of State Sovereignty (Soeverignty) which in principle states that the highest power in a country is law. All state equipment regardless of name, including citizens must obey and obey and uphold the law without exception. In order to guarantee legal certainty, order and protection, authentic written evidence is required regarding legal actions, agreements, decisions and events made before or by a notary. Therefore, in an effort to read the meaning of land certificates, or similar documents, a notary public needs to know, understand and understand that the birth certificate itself is based on natural law and natural rights and refers to the legal nature or law of land.

Notary is a public official appointed by the state whose aim is to serve the public as an impartial witness in committing various fraud prevention crimes related to the signing of important documents (Indiana Notary Public Guide, 2020: 5). ". At this time, the position of Notary is regulated by Law Number 30 of 2004 concerning Notary Position as amended by Law Number 2 of 2014 concerning Amendments to Law Number 30 of 2004 concerning the Position of Notary which was ratified by the President of the Republic of Indonesia Susilo Bambang Yudhoyono on January 15, 2014 in Jakarta, and the Minister of Law and Human Rights Amir Syamsudin was promulgated on January 15, 2014 in Jakarta and placed on the State Gazette of the Republic of Indonesia Year 2014 Number 3. Explanation of Law Number 2 of 2014 concerning Amendments to the Law Number 30 of 2004 concerning the Position of Notary Public is placed in an Supplement to the State Gazette of the Republic of Indonesia Number 5491.

The role of a notary in the service sector is as an official who is authorized by the state to serve the public in the civil sector, especially the making of authentic deeds, as regulated in Article 1 paragraph (1) of Law Number 30 of 2004 concerning the Position of Notary Public, (hereinafter abbreviated as UUJN ): "Notary is a public official who has the authority to make authentic deeds and other powers as referred to in this law. Notaries as public officials who carry out the profession in providing legal services to the public, need protection and guarantees in order to achieve legal certainty. The guarantee of protection and guarantee of attaining legal certainty for the implementation of the duties of a Notary is regulated in Law Number 30 of 2004 concerning the Position of a Notary Public. However, several provisions in the Law are no longer in accordance with legal developments and the needs of the community so that changes need to be made, which are also intended to further affirm and strengthen the duties, functions and powers of Notaries as officials who carry out public services, as well as synchronize with the law. -Other invitees. According to Law Number 2 of 2014 concerning Amendments to Law Number 30 of 2004 concerning the Position of Notary Article 15 paragraphs (1), (2), and (3) it reads as follows:

a. The notary is authorized to make authentic Deeds regarding all actions, agreements, and stipulations required by laws and regulations and / or those interested in being stated in the authentic Deed, guarantees the certainty of the date of making the Deed, keeps the Deed, provides grosse, copies and excerpts of the Deed, all of this as long as the making of the Deed is not assigned or excluded to other officials or other people as stipulated by law.

b. In addition to the authority as referred to in paragraph (1), the Notary is also authorized:

1) Ratify the signature and determine the certainty of the date of the letter under hand by registering in a special book;

2) Submitting letters under hand by registering in a special book;

3) Make a copy of the original letter under hand in the form of a copy containing the description as written and described in the letter concerned;

4) Conduct validation of the compatibility of the photocopy with the original letter;

5) Provide legal education in connection with making Deeds;

6) Making deeds relating to land; or

7) Prepare a deed of auction minutes.

c. In addition to the authorities as referred to in paragraph (1) and paragraph (2), Notary Public has other powers which are regulated in statutory regulations. More about this source textSource text required for additional translation information

The authority of a notary is regulated in the Law of the Republic of Indonesia Number 30 of 2004 concerning the Position of Notary Public (UUJN) Article 15 which regulates that the notary is authorized to 
make authentic deeds regarding all actions, agreements, and stipulations required by laws and regulations and / or those desired by who have an interest in being stated in the authentic deed, guarantee the certainty of the date of making the deed, keep the deed, provide grosse, copy and excerpt of the deed, all of which as long as the deed is made or not assigned or excluded to other officials or other people as stipulated by law. In addition to this authority, the notary is also authorized to record letters under hand by registering in a special book (Nabila, and Hoesin, 2020: 53-54). Then, in carrying out its duties, the Notary as the official making of the authentic deed, including the authentic deed relating to land as stated in Article 15 Paragraph (2) letter f of the UUJN, gives the notary authority to make deeds related to land.

Furthermore, the notary's job is to provide assistance on making authentic deeds. In this case, it is important for the notary to be able to understand the provisions regulated by law so that the general public who do not know or do not understand the rules of law, can understand correctly and do not do things that are against the law. (Andasasmita, 1983: 2). Legal certainty, order and protection demands, among other things, that legal traffic in people's lives requires evidence that clearly determines a person's rights and obligations as a legal subject in society (Rahman, 2020: 2). According to UUJN Article 16 paragraph (1), in carrying out their office, a Notary is obliged:

a. act honestly, thoroughly, independently, without taking sides, and protect the interests of the parties involved in legal actions;

b. make deeds in the form of Minuta Deeds and keep them as part of the Notary Protocol;

c. issue Grosse Deed, Copy of Deed, or Quotation of Deed based on Minuta Deed;

d. provide services in accordance with the provisions of this Law, unless there is a reason to refuse it;

e. keep everything concerning the deed he has drawn and all information obtained for the making of the deed in accordance with the oath / promise of office, unless the law stipulates otherwise;

f. bind the deeds that he makes in 1 (one) month into a book containing no more than 50 (fifty) deeds, and if the number of deeds cannot be contained in one book, the deeds can be bound into more than one book, and record the Minuta Deed, month and year of manufacture on the cover of each book;

g. make a list of deeds of protest against non-payment or non-receipt of securities;

h. make a list of deeds relating to wills according to the time line of making deeds each month;

i. send a list of deeds as referred to in letter h or a nil list relating to wills to the Central List of Wills of the Department whose duties and responsibilities are in the field of notary within 5 (five) days in the first week of each following month;

j. record in the repertorium the date of delivery of the testament at the end of each month;

$\mathrm{k}$. has a stamp / stamp bearing the symbol of the Republic of Indonesia and in the space surrounding it is written the name, position and domicile of the person concerned;

1. read out the deed in front of an audience in the presence of at least 2 (two) witnesses and signed at the same time by the audience, witnesses and a notary;

m. accepting internships for candidate Notaries.

Based on the various descriptions above, it can be interpreted that the duties, functions and authorities of a Notary as an official who carries out public services, the role of the Notary is very important to determine whether an action can be stated in the form of a deed or not. In making such a decision, the notary must have the ability to see, analyze and consider all documents shown and examine all evidence shown to him, listen to statements or statements of the parties. The decision must be based on legal reasons that must be explained to the parties (Kanter, E.Y, 2001).

Such considerations must take into account all legal aspects including legal issues that will arise at a later date. In addition, every deed made before or by a Notary Public must have reasons and facts that support the deed concerned or there are legal considerations that must be explained to the parties / parties. In carrying out his / her duties, a notary must remain in the corridors stipulated in UUJN and the Code of Ethics for the Position of a Notary. But in reality there are still notary deeds that are disputed by the parties and the cause 
of conflicts arises from deeds made by mistakes made by the notary itself or from other parties (Juliandari et.al, 2020) ..

Thus, the role and function of a Notary according to the Law of the Republic of Indonesia concerning the Position of Notary Public is to serve the public / the public in terms of their work obligations regulated by law, morals and professional ethics. In this case, notaries need to use a legal philosophy approach to ensure legal protection for the community of users of their services through accurate case mapping, legal corrections, linguistic improvements and comprehensive services (Rammou, 2020).

\section{Conclusions and Recommendations}

\section{a. Conclusions}

Certificate is strong evidence and issued for the purpose of proving the right holder concerned in accordance with the physical data and juridical data that has been registered in the land book listed in the certificate must match the data contained in the land book and the relevant measuring letter. The importance of land title certificates can be interpreted as the control of a person or individual over land as a human right that deserves protection and assurance of ownership. In order to guarantee legal certainty, order and protection, authentic written evidence is required regarding legal actions, agreements, decisions and events made before or by a notary. Notary as an official who carries out public services, the notary's role is very important to determine whether an action can be stated in the form of a deed or not. This is very important so that the Notary's deed is not disputed in the future by the parties so as to avoid the causes of conflict arising from the deed made by the Notary itself or from other parties.

\section{b. Recommendations}

Notaries are expected to have the ability to see, analyze and consider all documents shown and examine all evidence shown to them, listen to statements or statements of the parties through a philosophical approach to law. This is very important when the Notary makes decisions regarding the interests and lives of many people, especially related to land certificates. Such decisions and considerations must take into account all legal aspects including legal issues that will arise at a later date because every deed made before or by a Notary Public must have reasons and facts that support the deed concerned or there are legal considerations that must be explained to the parties / taper. In carrying out his / her duties, a notary must remain in the corridors stipulated in UUJN and the Code of Ethics for the Position of a Notary.

\section{References}

[1] Andasasmita, Komar.((1983) Notaris Selayang Pandang, Cet. 2, Bandung: Alumni

[2] Aryono, Eko. (2017). Analisis Politik Kebijakan Pertanahan Masa Orde Baru

[3] (Studi Kasus Mengenai Kedudukan Tanah Sebagai Fungsi Sosial Dan Fungsi Komoditas). Artikel Seputar Pemerintahan. http://ekoaryono11.blogspot.com /2017/ 06/analisis-politik-kebijakanpertanahan.html ((Accessed on 1 Desember 2020).

[4] Budiono, Agus. Slide Kuliah Metode Penelitian Hukum di Magister Kenotariatan Universitas Pelita Harapan. Jakarta: Universitas Pelita Harapan,2016

[5] Erwinsyahbana, Tengku.( 2018). PERSPEKTIF NEGARA HUKUM INDONESIA BERDASARKAN PANCASILA . https://www.researchgate.net/publication/32613 8919 . pp 1-20

[6] Fadli, Ardiansyah. "Konflik Pertanahan 9.000 Kasus, Pengamat Sarankan Pemerintah Bagi-bagi Tanah", https://www.kompas.com/properti/read/ 2020/ 11/04/ 185030121/konflik-pertanahan-9000kasus-pengamat-sarankan-pemerintah-bagi-bagi (Accessed on 30 November 2020).

[7] Herrayani,Dessy Ghea; Soraya ,Lucky Faradila; Moechtar, Oemar. (2019).Eksistensi Hak Komunal Masyarakat Hukum Adat dalam Kebijakan Penataan Aset Reforma Agraria. Jurnal Kertha Patrika, Vol. 41, No. 3 Desember 2019, pp. 283 - 299

[8] Indiana Notary Public Guide, "Office of the Indiana Secretary of State - Business Services Division", INBiz.in.gov, Revised August 25, 2020, https://inbiz.in.gov/ Assets/NotaryGuide.pdf (Accessed on 30 November 2020) 
[9] Indonesia - Land Degradation Neutrality National Report , REPUBLIC OF INDONESIA,https://knowledge.unccd.int/sites/default/files/inline-files/indonesia ldn country report. pdf (Accessed on 30 November 2020)

[10] Jones, Sidney .(2013). "The Growing Problem of Land Conflicts in Indonesia", BUSINESS, ENVIRONMENT, GOVERNANCE, INDONESIA by cogitASIA August 15, 2013. http://www.cogitasia.com/the-growing-problem-of-land-conflicts-in-indonesia/ (Accessed on 30 November 2020)

[11] Juliantari,Ni Nyoman; Bachri,Syamsul ; Patittingi, Farida. (2020) PELAKSANAAN KEWAJIBAN NOTARIS TERHADAP KUALITAS PRODUK AKTA DAN AKIBAT HUKUMNYA EXECUTION OF OBLIGATION NOTARY TO QUALITY PRODUCT ACT AND ITS LEGAL CONSEQUENCES Magister Kenotariatan Fakultas Hukum Universitas Hasanuddin. http://pasca.unhas.ac.id/jurnal/files/1409c9dfd66785626872d81e8a951fc6.pdf (Accessed on 30 November 2020)

[12] Kanter, E.Y. (2001). Etika Profesi Hukum Sebuah Pendekatan Sosio-Religius. Storia Grafika.

[13] Marzuki, Peter Mahmud. (2005).Penelitian Hukum. Jakarta : Kencana

[14] Mello, Michael. (2019). THE PHILOSOPHY OF LAW 1. The Philosophy of Law California State University, $\quad$ Fresno. https://www.researchgate.net/publication/ 332798574_THE_PHILOSOPHY_OF_LAW_1_The_Philosophy_of_Law (Accessed on 1 Desember 2020).

[15] Nabila,Aziza Adlien; dan Hoesin, Siti Hajati.(2020). Kewenangan Notaris Berkaitan Dengan Surat Pernyataan Oper Hak Atas Tanah Garapan (Analisis Putusan Mahkamah Agung Republik Indonesia Nomor

122pk/Pdt/2019). ndonesian Notary jurnal Program Magister Kenotariatan Fakultas Hukum Universitas Indonesia Vol 2, No 3 (2020), pp 53- http://notary.ui.ac.id/index.php/home/article/view/1031/227 (Accessed on 1 Desember 2020).

[16] Rahman, Mokhamad Dafirul Fajar.(2020). KEWENANGAN, KEWAJIBAN NOTARIS DAN CALON NOTARIS DALAM MEMBUAT AKTA AUTENTIK Fakultas Hukum Universitas Brawijaya Program Studi Magister Kenotariatan. https://media.neliti.com/media/publications/34957ID-kewenangan-kewajiban-notaris-dan-calon-notaris-dalam-membuat-akta-autentik.pdf Accessed on 1 Desember 2020).

[17] Rammou, Evangela J., (2020). Notary Public. The Four Pillars of My Philosophy - Working Method. http://www.notarin-evirammou.gr/en/contents/view/15 Accessed on 2 Desember 2020).

[18] Sihombing, B.F. (2016). Evolusi Kebijakan Pertanahan Dalam Hukum Tanah Indonesia. Jakarta: FHUP Press

[19] Toussaint, Eric. (2019). Globalization from Christopher Columbus and Vasco da Gama until today. 6 January 2019 https://www.cadtm.org/Globalization-from-Christopher-Columbus-and-Vasco-daGama-until-today ((Accessed on 1 Desember 2020).

[20] Widowati, Christiani. (2013). HUKUM SEBAGAI NORMA SOSIAL MEMILIKI SIFAT MEWAJIBKAN.. ADIL: Journal of Law published by the Faculty of Law YARSI University. Vol 4, No 1. http://academicjournal.yarsi.ac.id/index.php/Jurnal-ADIL/index (Accessed on 30 November 2020).

[21] Undang-Undang Dasar Negara Republik Indonesia Tahun 1945

[22] Undang - Undang Republik Indonesia Nomor 30 tahun 2004 tentang Jabatan Notaris

[23] Undang-Undang tahun 1960 tentang Peraturan Dasar Pokok-Pokok Agraria

[24] Undang-Undang Nomor 2 tahun 2014 tentang Perubahan Atas Undang-Undang Nomor 30 tahun 2004 tentang Jabatan Notaris

[25] Wahanisa, Rofi et.al. (2010). SOSIALISASI PENTINGNYA KEPEMILIKAN SERTIFIKAT TANAH SEBAGAI BUKTI PENGUASAAN HAK MILIK ATAS TANAH BERDASAR PP NO. 24 TAHUN 1997 TENTANG PENDAFTARAN TANAH DI DESA JETIS KECAMATAN BANDUNGAN KABUPATEN SEMARANG. Jurnal Abdimas [p-ISSN: 1410-2765 Vol 14, No 2 (2010|. https://journal. unnes.ac.id/nju/index.php/abdimas/article/view/26 (Accessed on 1 Desember 2020). 
[26] Wignjosoebroto,Soetandyo.(2020).Mengkaji dan Meneliti Hukum Dalam Konsepnya Sebagai Realitas Sosial. https://soetandyo.wordpress.com/ 2010/08/19/ mengkaji-dan-meneliti-hukum-dalamkonsepnya-sebagai-realitas-sosial/ (Accessed on 1 Desember 2020).

[27] Wiradi, Gunawan. POSISI UUPA-1960 DALAM "HIRUK-PIKUK"NYA WACANA PEMBARUAN AGRARIA Makalah, disampaikan dalam Semiloka yang diselenggarakan oleh Komnas Ham bekerjasama dengan FSPI, dalam rangka memperingati Hari Tani Nasional ke-42, bertempat di gedung YTKI, Jakarta, tanggal 26-27 September 2002. http://kpa.or.id/assets/uploads/files/publikasi/c6734-20-09-02-gwr-posisi-uupa-60.pdf (Accessed on 30 November 2020) 